\title{
Class Ila HDAC Downregulation Contributes to Surgery-Induced Cognitive Impairment Through HMGB I-Mediated Inflammatory Response in the Hippocampi of Aged Mice [Corrigendum]
}

\author{
Huang C, Cai J, Jin S, et al. J Inflamm Res. 2021;14:2301- \\ The authors apologize for this error.
} 2315 .

The authors have advised there is an error in the affiliations listed for Yuan-Xiang Tao on page 2301. The author name "Yuan-xiang Tao "1,3" should read "Yuan-xiang Tao".

\section{Publish your work in this journal}

The Journal of Inflammation Research is an international, peerreviewed open-access journal that welcomes laboratory and clinical findings on the molecular basis, cell biology and pharmacology of inflammation including original research, reviews, symposium reports, hypothesis formation and commentaries on: acute/chronic inflammation; mediators of inflammation; cellular processes; molecular mechanisms; pharmacology and novel anti-inflammatory drugs; clinical conditions involving inflammation. The manuscript management system is completely online and includes a very quick and fair peerreview system. Visit http://www.dovepress.com/testimonials.php to read real quotes from published authors. 